\title{
The Tendency for Adolescent Girls to Feel Comfortable in Communicating About Puberty and Reproductive Health with their Families: A Systematic Review
}

\section{Eighty Mardiyan Kurniawati ${ }^{*}$, Ernawati ${ }^{1}$, Nur Anisah Rahmawati ${ }^{2}$, Cahyani Tiara Safitri ${ }^{3}$, Safa Salsabilla ${ }^{3}$}

\author{
${ }^{1}$ Department of Obstetrics and Gynecology, \\ Faculty of Medicine, Universitas Airlangga, Surabaya, Indonesia \\ 2Faculty of Public Health, Universitas Airlangga, Surabaya, Indonesia \\ ${ }^{3}$ Faculty of Medicine, Universitas Airlangga, Surabaya, Indonesia
}

*Corresponding author details: Eighty Mardiyan Kurniawati; eighty-m-k@fk.unair.ac.id

\begin{abstract}
Background: There are knowledge problems related to puberty and health problems among adolescent girls so that they cannot be confident in effectively handling changes in their bodies during puberty as well as longterm reproductive health.

Purpose: This study aims to systematically review the tendency for adolescent girls to feel comfortable in communicating about puberty and reproductive health with their families.

Method: Systematic review is conducted in accordance with the guidelines of Preferred Reporting Items for Systematic Review and Meta-Analyses (PRISMA). The search was conducted through PubMed, Google Scholar, and Science Direct databases on English studies from 2016-2021 published date.

Results: Adolescent girls feel free to discuss issues related to puberty such as the development of secondary sex characters, menarche, and menstruation with the mother due to feelings and gender-specific compatibility This is due to stigma and perceived taboos in sociocultural factors. Fluency in communication is also caused by various factors such as knowledge between family and children, the number of families and attitudes and ways of communication of parents.

Conclusion: Parental involvement is important in giving knowledge about reproductive health for adolescent girls but must ensure that the family have good knowledge and good ways of communication as well as approaches to overcome barriers in the gender perspective.
\end{abstract}

Keywords: reproductive health talk; adolescence; puberty; family; mother; daughter

\section{INTRODUCTION}

Adolescence is one of the assets of the progress of civilization. Their emerging abilities and health are the foundation for future economic and social growth, especially in an era of demographic aging. Young people aged 10-19 currently make up more than 1.2 billion, or $17 \%$ of humanity according to $2015 \mathrm{UN}$ data. Global policy has begun to absorb the lesson that, after success in child survival and health, the achievement of hard-earned developmental achievements in the first decade must be secured with support for critical maturation milestones in the second decade (1).

Adolescents undergo a process of changing into adulthood. Puberty is characterized by substantial increases and the emergence of sex differences in psychological disorders, patterns of physical activity, and risky behaviors, with implications on health and wellness disparities. Physical manifestations of puberty can be observed by developing adolescents, but are also visible to others, and can be exacerbated by gender or racial/ethnic stereotypes. These changes may signal to adults or friends that teens are now emerging adults, even though their chronological age is the same as their peers and classmates (who have more childlike appearances) (2).

There is a lack of knowledge related to puberty and health problems among adolescent girls. Adolescents need health education before and during their puberty to make them confident in effectively handling their body changes during puberty (3). The goals and attitudes of parents, communities, and institutions thrive under the weight of adolescent transformation (1). It's important that adults including parents, teachers, and doctors - have knowledge of and are sensitive to individual differences in physical development and implicit biases in adolescents in their own environment (2). Youth programs and policies provide opportunities for institutions and communities to support healthy youth development. Puberty education programs are universally important, as they provide essential knowledge and skills to help young people and their caregivers navigate the physical, emotional, and interpersonal changes of puberty with positive outcomes (4). Sources of information about reproductive health during puberty become a problem in adolescent development 
to understand themselves. Previous research has found that gadis-girls have inadequate knowledge about menstruation. Menarche as a trigger for girls to learn about menstruation is common. Most girls obtain information about menstruation and/or puberty from their mothers, although mothers are not necessarily the source of girls' choices to learn about these topics. Young teenage girls are less prepared for puberty and menstruation (5). Adolescence is a period of rapid biological and psychosocial change, which has an important impact on parent-child relationships. Parents and teens should reorganize responsibilities and move toward more egalitarian relationships. Although conflict between parents and children becomes more frequent and more intense during adolescence, it is also considered a means of negotiating relational change (6). Mothers worry about their daughters' exposure to risktaking behavior but aren't sure about how to talk to their daughters about how to avoid them, especially on topics related to sex (7). This study aims to systematically review the tendency for adolescents girls to feel comfortable in communicating about puberty and reproductive health with their families.

\section{METHOD}

\section{Study design and search strategy}

A systematic review was conducted to explore the tendency for adolescent girls to feel comfortable in communicating about puberty and reproductive health with their families. The preparation of the report is in accordance with the guidelines of Preferred Reporting Items for Systematic Review and Meta-Analyses (PRISMA).18 Searches are conducted through pubmed, Google Scholar, and Science
Direct databases on English studies in the span of 5 years from 2016-2021 using a combination of medical subject heading $(\mathrm{MeSH})$ terms and relevant keywords in different order: 'mother', 'puberty talk', 'reproductive health', 'adolescence'. In the articles found, researchers also reviewed literature that appeared in bibliography, including manuscripts that were not netted in electronic literature searches.

\section{Study selection}

The inclusion criteria applied in article selection are prospective observational studies or experimental design studies in English, evaluating barriers in maternal and child reproductive health communication from 2016-2021. The exclusion criteria for this study are case reports, animal studies, letters to editors, study reviews, abstracts without full text.

\section{Data extraction}

The authors perform title and/or abstract filtering independently of the included articles using the standard Microsoft Excel form. A third external collaborator is consulted to resolve disagreements in consensus. Research is included if it has clear objectives and information flows, appropriate methodologies and accountable conclusions.

\section{Abstraction and synthesis of data}

As suggested in a systematic review of the literature, analysis is based on the results and conclusions of each study. As a first step, the relevant results are extracted, sorted, and examined to identify subthema and theme. The synthesis is done by all authors.

\section{Flowchart study selection}

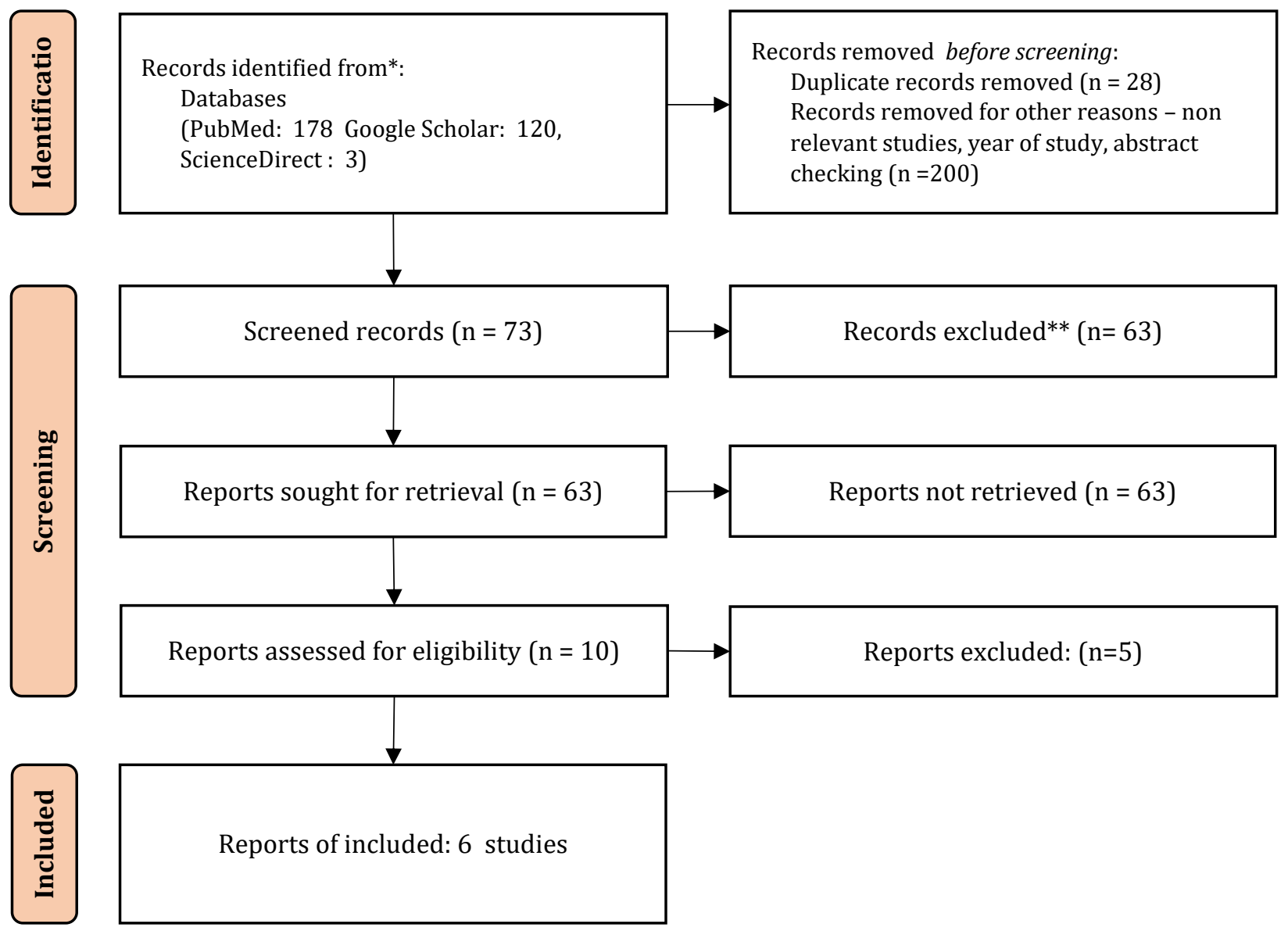

FIGURE 1: Prisma Flow Research 


\section{RESULTS}

The tendency of communication among adolescent girls is trending in the same gender. This is due to stigma and taboos that are felt in sociocultural factors. Fluency in communication is also caused by various factors such as knowledge between family and children, the number of families and attitudes and ways of communication of parents. The main source of knowledge about reproductive health from more than half of girls is from their mothers and the mother is the one who communicates first about reproductive health with teenage students (8).
A study found that more than half of mothers and adolescent girls have negative perceptions about communication about reproductive health issues (9). Girls feel free to discuss issues related to puberty such as the development of secondary sex characters, menarche, and menstruation with the mother due to feelings of genderspecific possessing and compatibility (10). Table 1 shows the factors influencing the tendency of adolescent comfort in communication about puberty and reproductive health.

TABLE 1: The factors that affect communication about puberty and reproductive health

\begin{tabular}{|c|c|c|c|c|c|}
\hline $\begin{array}{l}\text { Author, } \\
\text { year }\end{array}$ & country & $\begin{array}{l}\text { Number of } \\
\text { participants } \\
\text { (age) }\end{array}$ & $\begin{array}{l}\text { Type of } \\
\text { research }\end{array}$ & Data capture & Key findings (there are statistics) \\
\hline $\begin{array}{l}\text { Dhingra et al, } \\
2017(10)\end{array}$ & India & $\begin{array}{l}100 \text { girls in } \\
\text { the } 15-18 \\
\text { age group }\end{array}$ & $\begin{array}{l}\text { Cross } \\
\text { sectional } \\
\text { study }\end{array}$ & $\begin{array}{l}\text { In-depth self- } \\
\text { designed } \\
\text { interview } \\
\text { schedule - } \\
\text { descriptive } \\
\text { analysis }\end{array}$ & $\begin{array}{l}\text { Communication tends to pick } \\
\text { mothers out of hesitation, shame, } \\
\text { social norms and various stigmas } \\
\text { when communicating with their } \\
\text { families of different genders. }\end{array}$ \\
\hline $\begin{array}{l}\text { Noe e al, } \\
2018 \text { (9) }\end{array}$ & Myanmar & $\begin{array}{c}112 \text { pairs of } \\
\text { mothers and } \\
\text { adolescent } \\
\text { daughters }\end{array}$ & $\begin{array}{l}\text { A } \\
\text { community- } \\
\text { based, } \\
\text { cross- } \\
\text { sectional } \\
\text { study }\end{array}$ & $\begin{array}{l}\text { Face-to-face } \\
\text { interview } \\
\text { method with } \\
\text { semi-structured } \\
\text { questionnaires. }\end{array}$ & $\begin{array}{l}\text { The factors found to create barriers } \\
\text { to SRH communication were higher } \\
\text { family income, good knowledge of } \\
\text { puberty, good knowledge of sexual } \\
\text { and reproductive health issues and } \\
\text { perception of positive } \\
\text { communication among mothers. }\end{array}$ \\
\hline $\begin{array}{l}\text { Zakaria et al, } \\
2019 \text { (8) }\end{array}$ & Bangladesh & $\begin{array}{l}1174 \text { female } \\
\text { students } \\
\text { aged from } \\
13 \text { to } 19 \\
\text { years old }\end{array}$ & $\begin{array}{l}\text { cross- } \\
\text { sectional } \\
\text { study }\end{array}$ & Questionnaire & $\begin{array}{l}\text { Good knowledge of adolescent } \\
\text { students and mothers, mothers with } \\
\text { high media use, good mother- } \\
\text { daughter relationships, girls' regular } \\
\text { general communication with } \\
\text { mothers, and students' comfort in } \\
\text { reproductive health communication } \\
\text { with their mothers are significant } \\
\text { predictors for good communication } \\
\text { status. In contrast, students who had } \\
\text { family members numbering more } \\
\text { than four, whose primary sources of } \\
\text { reproductive health information } \\
\text { were friends/classmates as well as } \\
\text { the media were less likely to have } \\
\text { better communication with their } \\
\text { mothers. }\end{array}$ \\
\hline $\begin{array}{l}\text { Maina et al, } \\
2020(11)\end{array}$ & Kenya & $\begin{array}{l}\text { Thirty-two } \\
\text { parents and } \\
30 \text { teenage } \\
\text { boys and } \\
\text { girls aged } \\
\text { between } 11 \\
\text { and } 13\end{array}$ & $\begin{array}{l}\text { Qualitative } \\
\text { study }\end{array}$ & $\begin{array}{l}\text { Narrative } \\
\text { interview }\end{array}$ & $\begin{array}{l}\text { More girls than boys reported that } \\
\text { they had spoken to their parents } \\
\text { about reproductive health. While } \\
\text { communication does occur, there are } \\
\text { reactive, one-sided, and authoritarian } \\
\text { problems, and are often initiated by } \\
\text { parents. }\end{array}$ \\
\hline $\begin{array}{l}\text { Mirzaee et al, } \\
2019(12)\end{array}$ & Iran & $\begin{array}{l}4 \text { mothers } \\
\text { with teenage } \\
\text { girls at } \\
\text { puberty and } \\
6 \text { daughters. }\end{array}$ & $\begin{array}{l}\text { Qualitative } \\
\text { studies }\end{array}$ & $\begin{array}{l}\text { Semistructured } \\
\text { interview. }\end{array}$ & $\begin{array}{l}\text { Puberty talks are seen as } \\
\text { "inappropriate conversations with a } \\
\text { girl." There are several subthemas, } \\
\text { including "the mother's lack of } \\
\text { awareness regarding the role of } \\
\text { school, the mother's busy schedule, } \\
\text { and the adoption of alternatives to } \\
\text { mother-to-daughter talks". Different } \\
\text { sociocultural factors influence the } \\
\text { talk of puberty between mothers and } \\
\text { teenage girls. }\end{array}$ \\
\hline
\end{tabular}




\begin{tabular}{|c|c|c|c|c|c|}
\hline $\begin{array}{c}\text { Author, } \\
\text { year }\end{array}$ & country & $\begin{array}{c}\text { Number of } \\
\text { participants } \\
\text { (age) }\end{array}$ & $\begin{array}{c}\text { Type of } \\
\text { research }\end{array}$ & Data capture & Key findings (there are statistics) \\
\hline $\begin{array}{c}\text { Bikila et al, } \\
2021(13)\end{array}$ & Ethiopia & $\begin{array}{c}591 \\
\text { secondary } \\
\text { and } \\
\text { preparatory } \\
\text { school } \\
\text { students }\end{array}$ & $\begin{array}{c}\text { method } \\
\text { cross- } \\
\text { sectional } \\
\text { study }\end{array}$ & $\begin{array}{c}\text { mixed- } \\
\text { questionnaires, } \\
\text { and FGD was } \\
\text { conducted with } \\
\text { parents of } \\
\text { students }\end{array}$ & $\begin{array}{l}\text { self- } \\
\text { about SRH problems is low. Women, } \\
\text { who come from private schools, } \\
\text { paternal education, perceptions of } \\
\text { the importance of sex education, } \\
\text { sources of information on SRH issues } \\
\text { (schools and media), and the } \\
\text { mother's openness to communicate } \\
\text { about adolescent reproductive health } \\
\text { issues are identified as factors } \\
\text { associated with communication. }\end{array}$ \\
\hline
\end{tabular}

\section{DISCUSSION}

The tendency of communication among adolescent girls is trending in the same gender. This is due to stigma and taboos that are felt in sociocultural factors. According to research conducted internationally, both parents and children experience personal barriers, such as shame, discomfort and fear; communal barriers, such as outside sources and shifts in responsibility; and cultural barriers, such as sex as a taboo, focus on abstinence and age/generational differences (14).

Communication about sexual and reproductive health issues between parents and adolescents is still low. Hometo-house maternal health education and society are important for creating positive knowledge and attitudes about sexual and reproductive communication (15). Fluency in communication is caused by various factors such as knowledge between family and child, the number of families and attitudes and ways of communication of parents.

Adolescents may recall little or no communication with their mothers about sexual and reproductive health, and indicate that they have some degree of objection when discussing this topic with their current mothers. Taking these findings into account, mothers' communication on sexual and reproductive health topics should be removed from stigma in order for their daughters to have a more comprehensive education on these topics in adolescence. It's important for mothers to understand the long-term benefits of properly educating their daughters about the importance of sex and reproduction so they can develop a positive perspective on SRH as an adult (16).

Most girls make assumptions about their mother's statements and views due to lack of direct communication and report that most mothers don't change their conversational style to fit their daughter's understanding. In addition, this style of conversation has the potential to affect the entire household because siblings become other sources of reproductive health socialization and have the type of talk that reflects the type of parental talk (17).

\section{CONCLUSION}

Parental involvement is important in understanding adolescent reproductive health but the parent should have good knowledge and good ways of communication as well as approaches to overcome the barriers in the gender perspective.

\section{REFERENCES}

[1] Worthman CM, Dockray S, Marceau K. Puberty and the Evolution of Developmental Science. J Res Adolesc [Internet]. 2019 Mar;29(1):9-31. Available from: https://pubmed.ncbi.nlm.nih.gov/30869841
[2] Hoyt LT, Niu L, Pachucki MC, Chaku N. Timing of puberty in boys and girls: Implications for population health. SSM - Popul Heal [Internet]. 2020 Feb 4;10:100549. Available from: https://pubmed.ncbi.nlm.nih.gov/32099893

[3] Ali TS, Ali PA, Waheed H, Memon AA. Understanding of puberty and related health problems among female adolescents in Karachi, Pakistan. J Mr. Med Assoc. 2006;56(2):68-72.

[4] Crockett LJ, Deardorff J, Johnson M, Irwin C PA. Puberty Education in a Global Context: Knowledge Gaps, Opportunities, and Implications for Policy. J Res Adolesc. 2019;29(1):177-95.

[5] Coast E, Lattof SR, Strong J. Puberty and menstruation knowledge among young adolescents in low- and middle-income countries: a scoping review. Int J Public Health [Internet]. 2019/02/10. 2019 Mar;64(2):293304. Available from:

https://pubmed.ncbi.nlm.nih.gov/30740629

[6] Branje S. Development of Parent-Adolescent Relationships: Conflict Interactions as a Mechanism of Change. Child Dev Perspect. 2018;12(3):171-6.

[7] Matsuda Y, DeBastiani SD, Thalasinos RD, Ferranti D, De Santis JP, Iriarte E, et al. Hispanic MotherDaughter Communication About the Risks of Sex, Drugs, and Alcohol: Influences and the Strategies Mothers Use. J Pediatr Nurs [Internet]. 2021;61:32530. Available from:

https://www.sciencedirect.com/science/article/pii /S0882596321002591

[8] Zakaria M, Xu J, Karim F, Cheng F. Reproductive health communication between mother and adolescent daughter in Bangladesh: a cross-sectional study. Reprod Health [Internet]. 2019 Jul 24;16(1):114. Available from: https://pubmed.ncbi.nlm.nih.gov/31340826

[9] Noe MTN, Saw YM, Soe PP, Khaing M, Saw TN, Hamajima N, et al. Barriers between mothers and their adolescent daughters with regards to sexual and reproductive health communication in Taunggyi Township, Myanmar: What factors play important roles? PLoS One [Internet]. 2018 Dec 18;13(12):e0208849. Available from: https://doi.org/10.1371/journal.pone.0208849

[10] Dhingra R, Chauhan KS, Kachroo N. Parent adolescent communication related to pubertal issues. 2017;3(3):74-8. 
[11] Maina BW, Ushie BA, Kabiru CW. Parent-child sexual and reproductive health communication among very young adolescents in Korogocho informal settlement in Nairobi, Kenya. Reprod Health. 2020;17(1):1-14.

[12] Mirzaee F, Pouredalati M, Ahmadi A, Ghazaznfarpour M. Barriers to Puberty Talk between Mothers and Daughters: A Qualitative Study. Rev Bras Ginecol e Obstet. 2021;43(5):362-7.

[13] Bikila TS, Dida N, Bulto GA, Debelo BT, Temesgen K. Adolescents' Communication on Sexual and Reproductive Health Matters with Their Parents and Associated Factors among Secondary and Preparatory School Students in Ambo Town, Oromia, Ethiopia. Roy V, editor. Int J Reprod Med [Internet]. 2021;2021:6697837. Available from: https://doi.org/10.1155/2021/6697837

[14] Mullis MD, Kastrinos A, Wollney E, Taylor G, Bylund CL. International barriers to parent-child communication about sexual and reproductive health topics: a qualitative systematic review. Sex Educ [Internet]. 2021 Jul 4;21(4):387-403. Available from:https://doi.org/10.1080/14681811.2020.180 7316
[15] Ewnetu L, Mekonnen A, Alemu Y, Shume W. Parentadolescent communication about Sexual and Reproductive Health Issues and Associated Factors among Mothers in Wogdie District, North Ethiopia. 2021;1-22. Available from: https://doi.org/10.21203/rs.3.rs-138716/v1

[16] Nguyen D. Generational Differences Between Asian American Women and their Mothers and its Effects on Sexual and Reproductive Health Communication. Asian Am Res J. 2021;1(1).

[17] Leyser-Whalen O, Jenkins V. The Continuum of Sexual and Reproductive Health Talk Types Daughters have with Mothers and Siblings. Sex Res Soc Policy [Internet]. 2021; Available from: https://doi.org/10.1007/s13178-021-00553-2 